\title{
Does participatory forest management program lead to efficient forestresource use and improved rural livelihoods? Experiences from Mua -Livulezi Forest Reserve, Malawi
}

\author{
T.C Senganimalunje $e^{1,2 *}$,P.W. Chirwa ${ }^{2}$; F.D. Babalola ${ }^{2,3}$; M.A. Graham ${ }^{4}$ \\ ${ }^{1}$ Malawi College of Forestry and Wildlife, Private Bag 6, Dedza, Malawi \\ ${ }^{2}$ Forest Science Postgraduate Program, 5-15 Plant Sciences Complex, Faculty of Natural and \\ Agricultural Sciences, University of Pretoria, Hatfield, Pretoria 0028, South Africa \\ ${ }^{3}$ Department of Forest Resources Management, University of Ilorin, P.M.B 1515, Ilorin, Kwara \\ State, Nigeria. \\ ${ }^{4}$ Department of Information Science, 6-21 Information Technology Building, Faculty of \\ Engineering, Building and IT, University of Pretoria, Hatfield, Pretoria 0028, South Africa
}

*Corresponding author email: tchimsengani@gmail.com

\begin{abstract}
This study evaluates the efficacy of Improved Forest Management for Sustainable Livelihoods Program (IFMSLP) in communities adjacent to Mua-Livulezi Forest Reserve, Malawi. The program is specifically aimed at alleviating poverty and enhance rural livelihoods through promoting greater community involvement in forest management while providing access and associated benefits. The study therefore evaluated the effect of the program on community organisation, forest access, forest use, product availability and commercialisation of forest products. The results show that despite the program putting in place strategies for the people to access different products for different uses; forest use is restricted mainly to subsistence use rather than cash income. The main forest product collected by the people for livelihood was firewood, mainly for cooking and heating. This is an indication that forests are an important natural capital for subsistence rather than cash income. Gender, location of the village, and distance to the nearest forest area were significant predictors of households' forest use. Introduction of the co-management program has not brought out the expected outcomes in areas of community organization, forest access, forest product availability and commercialisation of forest products. A multi-institutional approach is recommended to draw upon diverse talents and experiences from individual institutions both government and non-governmental in order to achieve meaningful social change.
\end{abstract}

Key words: participatory forestry, forest use, forest access, community organisation, forest product availability, rural livelihoods. 


\section{INTRODUCTION}

Forest resources are increasingly being recognised as important for the livelihoods of people living in close proximity to forests (Angelsen and Wunder 2003; Yemiru et al. 2010). The World Bank (2004) estimated that about 1.6 billion people worldwide are dependent on forests for their livelihoods while other authors have also suggested that there are approximately $1.2-1.4$ billion forest dependent people (Chao 2012; FAO 2014). In Africa, the miombo sub region supports livelihoods of millions of people in both rural and urban areas (Njana et al. 2013, Shackleton and Gumbo 2010, Chidumayo and Marunda 2010, Dewees et al. 2010, Syampungani et al. 2009). Scoones (1998) and DFID (1999) defined a livelihood as comprising the capabilities, assets (both material and social resources) and activities required for a means of living.People's livelihoods comprise five core types of capitals upon which livelihoods are built: human, social, natural, physical capital and financial capital (Carney 2002, DFID 1999, Scoones 1998). Forests, as a natural capital, play an important role in the livelihoods of poor people through provision of food, energy, construction materials, medicine, fodder and agricultural implements (Warner 2000; Adedayo et al. 2010; Tumusiime et al. 2011). In addition, forests serve as a safety net in times of major, unpredictable events and shocks and as a possible route out of poverty through income generating activities (Fisher 2002; Cavendish 2003; Sunderlin et al. 2003; Kamanga et al. 2009; Angelsen et al. 2011).

In terms of utilisation of forest resources, poorer households, characterised by limited livelihood options, are more dependent on forest products than wealthier households but this is a function of specific products required (Cavendish 2003; Shackleton and Shackleton 2006; Shackleton et al. 2007; Jagger 2012; Hogarth and Belcher 2013; Vedeld and Sjaastad 2013). These differences in the utilisation are also reflected in the level of income generated from forests. Wealthier households use more high value products while the poor use low value forest products such as firewood and other non-timber forest products (Yemiru et al. 2010; Fisher 2002). Nevertheless, Vedeld at al. (2007) and Vedeld and Sjaastad (2013) have argued that despite low income from forests, the differences in dependence on income from forests may have a strong equalizing effect on local income distribution between low and high income households. Income from forest products has been reported to account for 30\% of all household income in Malawi (Fisher 2002), $33 \%$ in Ethiopia (Yemuri et al. 2010), 25\% in Mozambique (Hegde 2010), 26\% in Uganda (Jagger 2012) and 22\% overall in 17 developing countries (Vedeld et al. 2007) thereby making significant contributions to household economies in rural Africa.

Households' access and utilisation of forest products differ depending on socio-economic factors characterising the house, and this defines how the households build their livelihoods (Vedeld et al. 2007; Angelsen et al. 2011). There are two set of factors that exert great influence on how households access forest products: household specific and site specific factors. Household specific factors include household size, income, education, ethnicity, occupation, land size, livestock holding and sources of income (Adhikari et al. 2004; Jha 2008; Coulibaly-Lingani et al. 2009). Site specific factors include distance to and availability of forest resource, market access and participation in village institutions among others (Angelsen and Wunder 2003; Vedeld et al. 2004; Adhikari et al. 2004; Kabubo-Mariara 2008). Distance on one hand, can impair farmers' opportunities for more profitable activities (Gutierrez Rodriguez et al. 2009) while on the other can accelerate forest extraction when access to the forest and markets is better (Angelsen and 
Kaimowitz 1999, Mamo et al. 2007). Participation in village institutions and forest user groups enhances the dependence of a household on forest products because users gain rights to access forest products. It also positively influences the participation in forest activities and increases the willingness to participate in collective forest management work (Chhatre and Agrawal 2008; Kabubo-Mariara 2008).

In addition to the above factors, collection and utilisation of forest products is affected by seasonal variability. This variability reflects changes in labour distribution and changes in socioeconomic conditions. Seasonal variations in forest resource utilisation have been attributed to changes in labour availability over the year, variable demand of products across seasons, and ease at which related activities can be performed (Yemiru et al. 2010; Fisher 2002, 2005; Awasthi et al. 2003). These characteristics which define forest utilisation, need to be understood if the less powerful, who are more dependent on the forest resource, are not to be further marginalized (Barret et al. 2001; Schreckenberg et al. 2006).

Participatory Forestry Management (PFM) is a term that refers to a wide range of activities such as co-management, Joint Forest Management (JFM) and Community Forest Based Management (CBFM) that represent a new set of relationships between the state and communities adjacent to forests and woodlands (Schrekenberg et al. 2006). PFM has the potential to promote good governance, enhance sustainable forest management and livelihoods (Warner 2000; Menzies 2002). PFM has often been facilitated by donor funded projects (Menzies, 2002) and have often failed to deliver the expected and theoretically predicted outcomes (Blaikie 2006). However, PFM initiatives need to become mainstreamed within national and local government institutions so that they are more responsive to local situations (Thin and Gardingen, 2003; Blomley and Ramadhani, 2006).There is need to reconcile livelihood improvement and conservation through local enforcement and collective action in order to regulate the management and use of forests and forest products (Kaimowitz 2003; Chhatre and Agrawal 2008). Efforts towards this should follow an adaptive process, giving due attention to internal and external causal factors while at the same time conceptualizing what the possible outcomes might be (Salafsky and Wollenberg 2000; Sunderlin et al. 2005). This would allow for innovation and local adaptation of PFM processes that were developed by projects making them less costly and could be applied under different conditions (Matose, 2008). Thus allowing local people to shape social-environmental relationships in the way that suits them (Blaikie 2006).

In Malawi, PFM was initiated following policy changes in 1996 to allow for people's involvement in the conservation of trees, forests and protected forest areas (Kayambazinthu 2000; Ngulube et al. 2000). Several donor funded projects and programs were implemented following these institutional changes. The lessons from these initiatives informed the development of the standards and guidelines for implementation of participatory forestry in Malawi in 2005. The standards and guidelines identified seven practical actions to be implemented for sustainable forestry and livelihoods. These included: community management of customary forests; management of state forest reserves; co-management of state forest reserves; individual/household planting and trees on farm; afforestation, community involvement in the management of state plantations and; harvesting, processing, and marketing of forest produce (GoM 2005). The implementation of PFM was scaled up with the Improved Forest Management for Sustainable Management Program (IFMSLP) which was initiated in 2006. The 
program focused mainly on three of the practical actions for implementing participatory forestry in Malawi and these included community management of customary forests, co-management of state forests reserves and harvesting processing and marketing of forest produce (GoM, 2005).

\section{The Improved Forest Management for Sustainable Management Program (IFMSLP)}

The IFMSLP was a two phased donor funded participatory forestry program which run from 2006 to 2009 and 2011 to 2013.The aim of the program was to address poverty and enhance rural livelihoods through promoting greater community involvement in forest management while providing access and associated benefits (IFMSLP 2007). The program targeted forest reserves and their adjacent communities, where a co-management agreement was facilitated between the Department of Forestry (DoF) and the adjacent communities. The process followed a learning by doing approach which culminated in the development of the strategic forest area plan (SFAP)) for the forest reserve. The SFAP provided guidance on implementation of forestry interventions within the forest reserve and on customary lands. The reserve was zoned into blocks which were allocated to the adjacent communities following agreed boundaries while on customary land, village forest areas (VFAs) were demarcated. The SFAP therefore, provided the basis for development of management plans for both the blocks and VFAs. The communities were organised in forest user groups, whose representatives were elected to a village natural resources management committee (VNRMC). Representatives from several VNRMC were nominated and elected to form a block management committee (BMC). The BMC was mandated to oversee management of forest block within the forest reserve, which was allocated to the community they represented. Thereafter, the community was involved in the development of forest management plans for the forest block. The management planning process involved a participatory forest resource assessment which resulted in demarcating the forest block into forest management units (FMUs), determination of products that could be harvested and the annual allowable cut for the different products. The demarcation of the FMUs was based on what uses (including product harvesting) could be allowed in the FMU. Involvement of community members in development of management plans increased their awareness of strategic issues that affect overall condition and management of their forests. Corresponding management strategies and forest access and product use rules (targeting the specific products) were developed. This formed the basis for development of a local licensing system as a way of achieving regulated access to forest products. The system detailed the procedures to be followed to access specific forest products in the area under the community's jurisdiction. For example, users were required to get a permit to access forest products for subsistence use. However, for commercial use, users were required to pay a fee and dependent on product and quantity, a licence was issued. Forest based enterprise activities were developed based on the outcome of the management planning process and these included bee keeping, firewood selling, bamboo selling and curio making.

This study was therefore designed to evaluate the effect of the Improved Forest Management for Sustainable Livelihoods Program (IFMSLP) on efficient use of forest resources and rural livelihoods. Efficient forest resource use in this study refers to forest use that is regulated and institutionalised within the community, and is effective in controlling unregulated forest use. The specific research questions included: (i) what is the contribution of forest resources to rural livelihoods in communities adjacent to the forest reserve? (ii) How do resource utilization patterns compare in terms of seasonal variations? (iii) How has implementation of the improved 
forest management for sustainable livelihoods program affected forest use and people's livelihoods?

\section{RESEARCH DESIGN AND METHODS}

\subsection{Study area description}

Mua-Livulezi Forest Reserve located in Dedza district was one of the identified twelve forest areas that the program identified as focus areas for implementation of program activities. MuaLivulezi Forest Reserve (Figure 1), was gazetted in 1924 for soil and water conservation, cultural and aesthetic values (Department of Forestry 2007). It is within the Kirk Range escarpment which runs from Ntcheu to Salima districts and covers an area of 12,147 hectares. The Mountain lies at an altitude of $2000 \mathrm{~m}$ above sea-level and receives an average rainfall of $1600 \mathrm{~mm}$ per annum. Vegetation in the reserve include relics of evergreen forest and fire induced montane grassland on top with miombo woodlands occupying the plateau, the slopes and valley bottom. The most common species are Pterocarpus angolensis, Khaya anthotheca and Breonadia salicina with dense undergrowth of bamboos. The soils can broadly be classified as ferralitic latosols. Top soils are predominantly free draining sandy clay loams with a shallow humic layer and of variable depth. Wettest months are December and January and driest are September and October. The general pattern of drainage is radial with many small streams rising from the mountain side (Department of Forestry 2007).

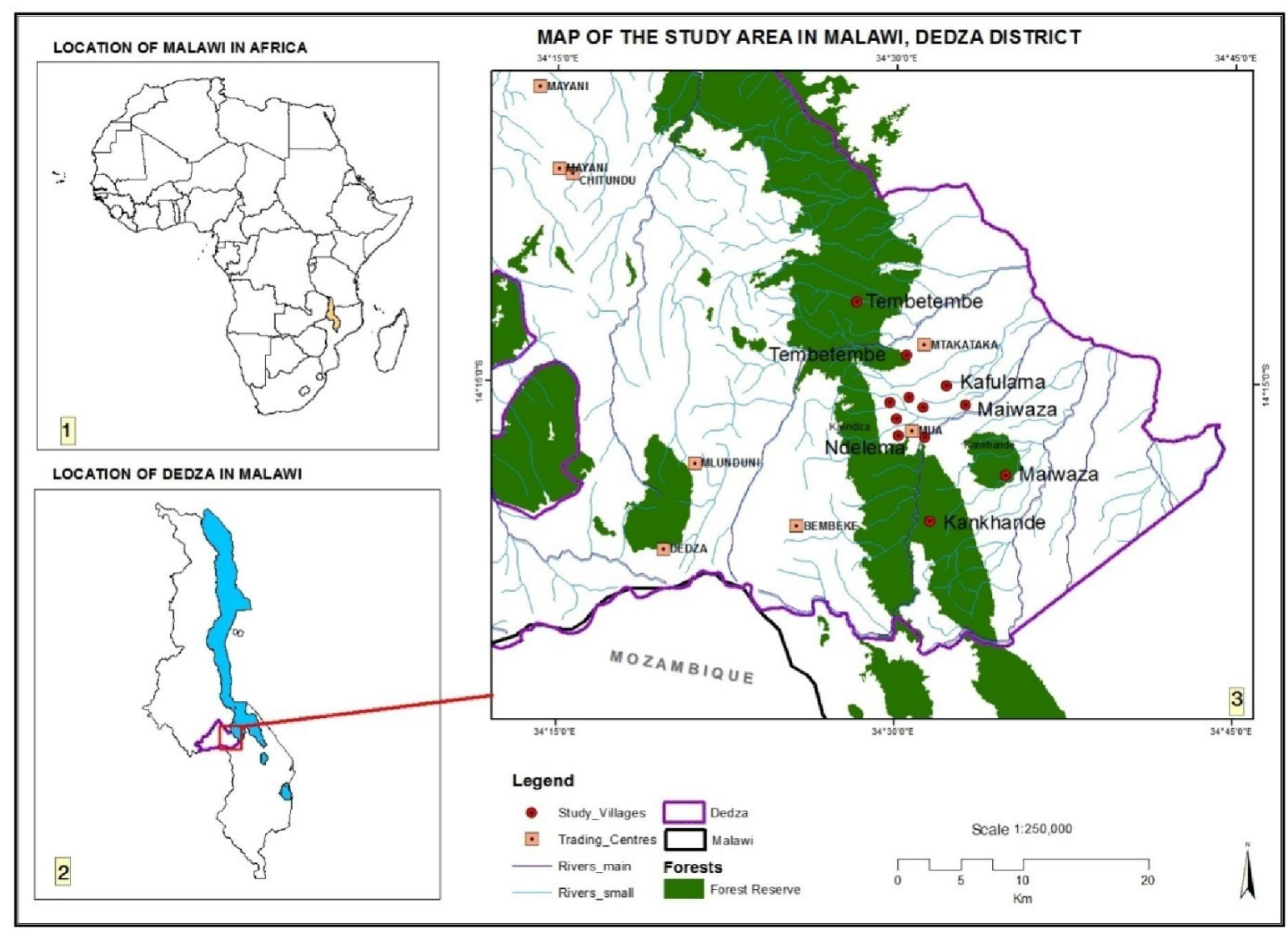

Figure 1. Map of study site (Source: GIS Unit, Department of Forestry) 
The rapid population increase in the area at an annual rate of $2.6 \%(\mathrm{GoM}, 2008)$ and proximity to Dedza town has increased demand for forest products such as firewood, timber, curio and nonwood forest products such as water for irrigation. The increased demand for water is due to the irrigation scheme currently covering 700 hectares. Most tree species of high timber value have been selectively felled and what remains are patches of indigenous woodlands. Other factors which have contributed to the heavy degradation are encroachment through establishment of illegal farms and settlements, illegal pit sawing, charcoal production and late bushfires (GoM, 2013).

The research area falls under Mtakataka extension planning area (EPA), which has a total land area of 29, 340 haand a population of 75,325. The EPA has 104 registered villages with 15,065 households. The households within Mtakataka EPA are subsistence farmers whose farm landholding size averages 0.8 ha. The main agricultural crops grown include maize, groundnuts, beans, cassava, and sweet potatoes. In addition, people in the area keep livestock mainly cattle, goats, sheep, pigs, and chickens. These agricultural products are used for household consumption and for sale to purchase other household necessities (Department of Forestry 2007). For the purpose of this study, the villages were divided into two categories: upland and lowland, because it was believed that distance to the reserve might influence forest use and availability. The upland villages are closer to the forest reserve within a radius of $2 \mathrm{~km}$, the market trading centre and the Catholic Mua Mission. The lowland villages are within 3-5 km radius of the forest reserve and the main trading centre (Mtakataka, Figure 1, part 3).

\subsection{Sampling framework and Data Collection}

The research targeted co-management sites and therefore Mua-Livulezi Forest Reserve, being one of the target forest areas for IFMSLP, and its adjacent communities were purposively selected to suit the focus and context of the study. Purposive sampling is a non-probability sampling technique in which decisions regarding selection of the sample are based on a variety of criteria to select a sample that provides appropriate data, both in terms of relevance and depth (Palinkas et al. 2013; Palys 2008; Suri 2011; Tongco 2007 ) Eleven villages out of thirty seven participating villages (about 30\%) were randomly selected. The villages are in the area of Group Village Headman (GVH) Kafulama in Traditional Authority Kachindamoto, in Mtakataka, Dedza (GoM 2013). A list of households for each village was developed based on information from village registers provided by village headmen. Proportional random sampling (based on number of households in each village) was used to select households for interviews to allow for a representative sample from each village and reduce sampling error (Palinkas et al., 2013, Scheaffer et al. 2012). A total of 300 household were selected.

Two data collection methods were used namely: focus group discussions and household interviews. Household interviews were conducted with the head of household or an adult person (in the absence of head of house) to represent the views of the selected household. In cases where the household could not be interviewed, the next randomly selected household on the sampling framework was selected. A structured questionnaire used to conduct household interviews was adapted from The Poverty Environment Network (PEN) prototype questionnaire to suit the objectives and focus of the study (CIFOR 2008). A total of 300 household were selected for 
interviews. The questionnaire captured information related to household demographics, main forest products for livelihoods, utilisation patterns in terms of frequency and quantity of collection and changes in resource availability, and community perception of the IFMSLP. The group discussions were conducted with non-committee community members to get an overall impression of PFM in the area. The groups were segregated by gender with one group comprising of 23 women and the other 15 men. The discussions, which lasted one hour, focused on forest product preference/ranking using a matrix, seasonal variation in forest product availability, co-management process, participation in meetings and other forestry activities and awareness of forest use procedures and main sources of income. Furthermore, a transect walk was conducted to get an overall picture of the condition of the forest.

\subsection{Data analysis}

Data obtained through the questionnaire were coded and processed using Statistical Package for Social Scientists (SPSS Ver22) to generate descriptive statistics. Descriptive statistics were generated for data on household demographics, forest use, effect of season on quantity of forest product, and implications on forest products availability. Further analysis was done using Statistical Analysis Software (SAS Enterprise Guide Ver4.3). In order to assess the significance of socio-economic determinants of forest use, two logistic regression models were developed (Peng et al. 2002). The dependent (forest use) variables used were main forest product for livelihood and frequency of forest product collection. For the main forest product for livelihood, with two levels, a binary logistic model was fitted to estimate odds ratios (y), while for frequency of forest product collection a cumulative logit regression model was used because it had more than two levels.

Odds ratios were used to quantify the strength of the existence or absence of relationship between the outcome variables and the predictor variables. In essence, the logistic model predicts the logit of outcome variable $(\mathrm{Y})$ from the predictor variables $(\mathrm{X})$. The logit is the natural logarithm $(\mathrm{ln})$ of odds of $\mathrm{Y}$, and odds are ratios of probabilities $(\pi)$ of $\mathrm{Y}$ happening to probabilities $(1-\pi)$ of Y not happening. The logistical model equation has the form:

$$
\ln \left(\frac{\pi}{1-\pi}\right)=\beta_{0}+\beta_{1} X_{1 i}+\beta_{2} X_{2 i} \ldots \ldots \ldots+\beta_{k} X_{k i}
$$

Where $\beta_{0}$ is the $\mathrm{Y}$ intercept and $\beta_{1}, \beta_{2} \ldots \ldots \beta_{\mathrm{k}}$ are the coefficients for the predictor variables and $\mathrm{X}_{1}, \mathrm{X}_{2} \ldots \ldots \mathrm{X}_{\mathrm{k}}$ are the predictor variables.

Since about $90 \%$ of the total respondents chose firewood as their main forest product for livelihood, firewood was therefore selected for further analysis. The categorization of predictor variables was based on the distribution of responses in regard to the variables in Tables 1 and 2 . The predictor variables contained in the model included gender, village, age, education, household size, land size, and distance to nearest forest area. These variables were entered into the analysis as 0 or 1 for the dichotomous outcome, continuous values for continuous predictors and dummy codings $(0$ or 1$)$ for categorical predictors. One category of each variable was taken as a reference and the basis for the selection of reference category was previous research and the expectations from the study itself. 


\section{RESULTS AND DISCUSSION}

\subsection{Household characteristics}

The survey indicated that the average household size for all the sampled villages was 5 members and majority of the households were headed by women. Table 1 indicates the demographic profile of the households. The average age was 39.8, of which $81 \%$ were women. With respect to education, $13 \%$ of the respondents never attended school, $73 \%$ attended primary education, $12 \%$ attended secondary education and only $2 \%$ had post-secondary education. The households owned land through customary freehold with $58 \%$ of the respondents indicating that they 'owned' less than 1 ha. The majority ( $72 \%$ ) did not belong to any forestry related group.

\section{Table 1. Household characteristics}

\begin{tabular}{|c|c|c|}
\hline Characteristic & Frequency & Percentage \\
\hline \multicolumn{3}{|l|}{ Gender } \\
\hline Male & 57 & 19.0 \\
\hline Female & 243 & 81.0 \\
\hline \multicolumn{3}{|l|}{ Age group (years) } \\
\hline $17-25$ & 60 & 20.0 \\
\hline $26-35$ & 90 & 30.0 \\
\hline $36-45$ & 62 & 20.7 \\
\hline $46-55$ & 32 & 10.7 \\
\hline$>55$ & 57 & 19.0 \\
\hline Mean & 39.76 & \\
\hline Std. deviation & 15.919 & \\
\hline \multicolumn{3}{|l|}{ Education } \\
\hline No education & 29 & 13.0 \\
\hline Primary & 219 & 73.0 \\
\hline Secondary & 36 & 12.0 \\
\hline Tertiary & 6 & 2.0 \\
\hline \multicolumn{3}{|l|}{ Land size } \\
\hline No land & 25 & 8.3 \\
\hline$<1$ ha & 174 & 58.0 \\
\hline $1 \mathrm{ha}$ & 36 & 12.0 \\
\hline$>$ 1ha & 65 & 21.7 \\
\hline \multicolumn{3}{|l|}{ Household size } \\
\hline $1-5$ & 175 & 58.3 \\
\hline $6-10$ & 125 & 41.7 \\
\hline Mean & 5.14 & \\
\hline Std. Deviation & 1.886 & \\
\hline \multicolumn{3}{|c|}{$\begin{array}{l}\text { Membership in forest related } \\
\text { groups }\end{array}$} \\
\hline Yes & 84 & 28.0 \\
\hline No & 216 & 72.0 \\
\hline
\end{tabular}




\subsection{Household forest use}

The management plan facilitated by IFMSLP indicated that the main product to be harvested from the forest block was firewood with poles and timber as by-products (Department of Forestry 2007). Other products that were to be collected included medicines, honey, quarry stones, fruits, fish, bamboos, thatch grass, mushrooms, bush meat and wild vegetables. The results agree with what was in the plan as regards the main product (Table 2). The household interviews revealed that main forest product collected by the majority $(91.6 \%)$ was firewood, with the remaining $8.4 \%$ collecting wood for construction $(4.7 \%)$ and non-timber forest products (3.7\%).

\section{Table 2. Household use of forests}

\begin{tabular}{|c|c|c|}
\hline Aspect & Frequency & Percentage \\
\hline \multicolumn{3}{|l|}{ Distance to forest area } \\
\hline $0-5 \mathrm{~km}$ & 257 & 86.2 \\
\hline $6-10 \mathrm{~km}$ & 33 & 11.1 \\
\hline $11-15 \mathrm{~km}$ & 8 & 2.7 \\
\hline \multicolumn{3}{|l|}{ Main forest product } \\
\hline Firewood & 274 & 91.6 \\
\hline Wood for construction & 14 & 4.7 \\
\hline Other NTFPs & 11 & 3.7 \\
\hline \multicolumn{3}{|l|}{ Source of forest product collection } \\
\hline Forest reserve & 155 & 51.7 \\
\hline Village forest area & 36 & 12.0 \\
\hline Group/communal forest & 33 & 11.0 \\
\hline Own forest/garden & 68 & 22.7 \\
\hline Buying & 3 & 1.0 \\
\hline Other people's forests & 5 & 1.7 \\
\hline \multicolumn{3}{|l|}{ Who collects } \\
\hline Women & 204 & 70.6 \\
\hline Men & 45 & 15.6 \\
\hline Children & 37 & 12.8 \\
\hline Employed labourers & 3 & 1.0 \\
\hline \multicolumn{3}{|l|}{$\begin{array}{l}\text { Frequency of forest product } \\
\text { collection }\end{array}$} \\
\hline No collection & 7 & 2.3 \\
\hline Daily & 30 & 10.0 \\
\hline Once a week & 206 & 68.7 \\
\hline Once a month & 57 & 19.0 \\
\hline \multicolumn{3}{|l|}{ Use in livelihood activities } \\
\hline Own consumption & 275 & 92.0 \\
\hline Sale & 24 & 8.0 \\
\hline
\end{tabular}


Use of firewood as a source of fuel for cooking and heating was supported by results from focus group discussions on preference ranking of forest products (Table 3) which indicated that firewood was ranked the most important forest product for women whereas timber was ranked most important by men. However, jointly men and women ranked firewood as the most preferred product, followed by bamboos, timber, thatch grass, and palms.

Table 3. Forest product ranking

\begin{tabular}{llll}
\hline Forest product & Joint ranking* & Men's ranking* & Women's ranking* \\
\hline Firewood & 1 & 3 & 1 \\
\hline Bamboos & 2 & 2 & 4 \\
\hline Timber & 3 & 1 & 5 \\
\hline Thatch glass & 4 & 4 & 2 \\
\hline Palms & 5 & 5 & 3 \\
\hline
\end{tabular}

*1 highest preference; 5 lowest preference.

Furthermore, this finding is consistent with national energy use in Malawi as most households $(>90 \%)$ use firewood and charcoal as their main source of fuel (Eneya and Saka 2007, unpubl, Zulu 2010, 2013; Yaron et al. 2011). Similar trends have been reported by Syampungani et al. (2009) for Southern Africa where firewood and charcoal constitute $70 \%$ of the energy consumed. Nationally, there are three main sources of firewood: forest reserves, customary forests/lands and plantation forests contributing $26 \%, 37 \%$ and $11 \%$ of total firewood supply (Jumbe and Angelsen 2006). From the study, 52\% of the households collected firewood from the reserve, an indication of the importance of the reserve as a source of fuel. This exerts pressure on the forest reserve as a source of firewood. Despite the management plan spelling out the product resource rules for harvesting forest products for commercial purposes, the majority $(92 \%)$ of the households interviewed indicated that they used the forest products for their own consumption with only few indicating that they sold the forest products collected. Thus, current forest use is mainly restricted to subsistence use; an indication that the forest is an important natural capital for subsistence rather than a cash income strategy. Similar results were reported in forestdependent communities in northern Pakistan (Ali et al. 2007) and in West Africa (Pouliot and Treue, 2012). Our results (Table 2) showed that women are the main collectors of firewood. However men were involved in the collection activities. This result is consistent with what Sunderland et al. (2014) found in a global comparative study; where it was shown that despite significant gender differentiation in the collection of forest products, men in Africa contribute substantially to firewood collection. In most cases, men collect forest products, including firewood, predominantly for sale and, in some instances, having exclusive control (Cavendish, 2000; Coulibaly-Lingani et al. 2009; Shackleton et al. 2011; Sunderland et al. 2014).

Forests are known to supplement household income and improve living standards when communities are engaged in value addition and sale of high value forest products (Sunderlin et al. 2005; Fisher 2004; Babulo et al. 2008; Kamanga et al. 2009; Ra et al. 2011). However, in this study, only few respondents (about 8\%) adjacent to Mua-Livulezi Forest Reserve indicated that they sell products collected from the forest but claimed that valuable timber species were (illegally) selectively harvested. This may be attributed to lack of access to markets that would 
have allowed for increased income to be made from the sale of natural resources (Paumgarten 2005). The markets around Mua-Livulezi were small with little commercialisation of most forest products including firewood. In addition, forest based enterprises which were hoped to increase income from forests never took off as the community was still waiting for the initial support (from IFMSLP) to develop the products and establish markets. This resulted in the communities missing out on the opportunities presented by the forest reserve. Shackleton et al. (2008) reported that income from forest products, in South Africa, played a critical role in people's livelihoods delivering a range of financial and non-financial benefits through provision of additional sources for income generation, income diversification, a safety net, reduced reliance on welfare and cash for specific needs. This was attributed to availability of markets for products such as woodcraft, reed mats, traditional brooms and a traditional beer.

\subsection{Factors influencing household forest use}

Table 4 presents the results of the logistic regression analysis of the predictor variables which were expected to influence forest use. All predictor variables had positive association with forest use. However, this association (influence) was significant for gender $(p=.0003)$, village category (location) $(p=.0092)$ and distance to the nearest forest area $(p=.0014)$. Gender was significant implying that women are more likely to choose firewood as their main forest product compared to men. Gender is associated with choice of main livelihood product and this result is linked to preference for forest products in the area. Focus group discussions revealed differences in preferences for forest products among men and women. Firewood was ranked the most important forest product for women whereas for men, timber was ranked most important. Timber could have substantially increased income from forests and therefore, improve the welfare of the households. Timber from indigenous wood is highly sought, and therefore highly marketable. However, restrictions on its harvesting by both government and the community, has relegated the importance that timber could have played in livelihoods. In the study area, it was often women who collected firewood for home use and sometimes for sale. This result partly supports findings of Sunderland et al., (2014) that women in sub-Saharan Africa harvest more unprocessed products. Other studies have also shown that women use a wider variety of forest resources, usually for subsistence, than men who tend to collect higher value forest products (Paumgarten 2005; Barrow et al. 2007; Coulibaly-Lingani et al. 2009; Adedayo et al. 2010; Pouliot and Treue 2012).

Table 4. Factors influencing household forest use

\begin{tabular}{llllll}
\hline Forest Use & Independent variables & Odds ratio & Lower & Upper & p-value \\
\hline Main forest & Village category upland & $(1)$ & & & \\
product for & Village category lowland & 1.314 & 0.553 & 3.124 & 0.5367 \\
livelihood & Age group years (17-25) & $(1)$ & & & \\
& Age group years (26-35) & 1.099 & 0.228 & 4.190 & 0.8236 \\
& Age group years (36-45) & 2.243 & 0.419 & 11.991 & 0.2149 \\
& Age group years (46-55) & 0.967 & 0.188 & 4.968 & 0.6661 \\
& Age group years (>55) & 1.019 & 0.242 & 4.295 & 0.7033 \\
& Gender (male) & $(1)$ & & & \\
& Gender (female) & 4.824 & 2.040 & 11.410 & $0.0003^{*}$ \\
& Education level (no schooling) & $(1)$ & & & \\
\hline
\end{tabular}




\begin{tabular}{|c|c|c|c|c|c|}
\hline & Education level (primary) & 1.304 & 0.323 & 5.267 & 0.1916 \\
\hline & Education level (secondary) & 0.213 & 0.022 & 2.072 & 0.2145 \\
\hline & Education level (tertiary) & 0.545 & 0.184 & 1.611 & 0.7982 \\
\hline & Household size (1-5) & (1) & & & \\
\hline & Household size (6-10) & 1.163 & 0.458 & 2.955 & 0.7510 \\
\hline & Land size (no land) & (1) & & & \\
\hline & Land size $(<1 \mathrm{ha})$ & 1.004 & 0.200 & 5.037 & 0.9969 \\
\hline & Land size (1ha) & 0.988 & 0.144 & 6.757 & 0.9757 \\
\hline & Land size $(>1$ ha $)$ & 1.021 & 0.171 & 6.099 & 0.9683 \\
\hline & Distance to forest area $(0-5 \mathrm{~km})$ & (1) & & & \\
\hline & $\begin{array}{l}\text { Distance to Forest area (6- } \\
10 \mathrm{~km})\end{array}$ & 0.369 & 0.124 & 1.097 & 0.2068 \\
\hline & $\begin{array}{l}\text { Distance to forest area (11- } \\
15 \mathrm{~km})\end{array}$ & 1.118 & 0.077 & 16.134 & 0.6546 \\
\hline \multirow{7}{*}{$\begin{array}{l}\text { Frequency of } \\
\text { forest product } \\
\text { collection }\end{array}$} & Village category & 2.129 & 1.206 & 3.757 & $0.0092 *$ \\
\hline & Age & 0.970 & 0.485 & 1.941 & 0.9313 \\
\hline & Gender & 1.063 & 0.875 & 1.291 & 0.5374 \\
\hline & Education & 0.900 & 0.703 & 1.152 & 0.4026 \\
\hline & Household size & 0.995 & 0.868 & 1.140 & 0.9428 \\
\hline & Land size & 1.272 & 0.943 & 1.716 & 0.1156 \\
\hline & Distance to forest area & 0.396 & 0.225 & 0.699 & $0.0014 *$ \\
\hline
\end{tabular}

* Significant at $p=0.05$

The regression analysis also showed that location of the village and distance to nearest forest area had a positive and significant relationship with forest resource use. This result implied that despite the forest area being at a further distance, people were willing to go as far as necessary to collect the products they required. This is confirmed by the results which showed that the majority of the households $(86.2 \%)$ were located within $5 \mathrm{~km}$ of the nearest forest area. In fact, the study showed that households that were farther from the forest $(>5 \mathrm{~km})$ still accessed the forest. This is consistent with findings in Malawi (Biran et al. 2004; Kambani 2005) and elsewhere (Cooke et al. 2008; WFP 2010) which revealed that women can travel long distances to collect firewood. Similarly Adhikari et al. (2004) reported that distance was not among the factors that hindered access to the forest for firewood collection in mid hills of Nepal. Other authors, however, have reported that households that are closer to the forest area have more secure and accessible supply of forest products than those that are located far from the forest (Paumgarten 2005; Saptoka, and Odén 2008; Kabubo-Mariara 2008).

The distance to forest area can also be linked to commercialisation of the forest products. Proximity to the resource allows household to access products at a lower costs as opposed to households that are remote. This has implication on both entitlement to the resource and profitability (Mamo et al 2007). However, this linkage is affected by other factors such as access to markets. Access to markets is determined by the condition of infrastructure such as access roads that link households to markets, market networks and cooperatives, As earlier indicated, the markets (for forest products) around Mua-Livulezi were small associated with low patronage, hence may not be the appropriate avenue for selling the forest products. Therefore, collection of forest products for sale was rare as the returns did not match the time and energy spent on their collection. Despite the site having access to good roads which can link the people to viable markets for forest products, this opportunity is not taken due to additional investment in form of 
transportation costs. This is in agreement with Gutierrez Rodriguez et al. (2009) who reported that distance can impair farmers' opportunities for more profitable activities. However, sourcing additional funding to invest in forest based enterprises could have been easier if users were organised in cooperatives that could have a better chance to access credit than individuals.

Although the study showed that age and education were not statistically significant to influence forest use, the regression analysis, however, showed that the odds ratios for these factors were positive. This indicated that any change in these factors would result in a positive influence in forest use. This brings the results closer to what other authors have reported. Age has been reported to influence collection of forest products, as it relies on physical strength; forest dependence may reduce as people advance in age (Godoy et al. 1997; Cavendish 2000; Vedeld et al. 2004; Paumgarten 2005; Mamo et al. 2007; Coulibany-Lingani et al. 2009). Higher levels of education open up employment opportunities and movement out of subsistence agriculture resulting in reduced use of forest resources (Adhikari et al. 2004; Vedeld et al. 2004; Mamo et al. 2007). Data collection on forest use for longer periods of time might help to explain the contradiction. For land size, however, the results agree with what was reported by Shackleton and Shackleton (2004) and Kabubo-Mariara (2008) that land size and household size, proved to be insignificant predictors for forest use in other studies. Understanding these factors will reveal the patterns of resource use (preference and dependence) and the characteristics of the users which determine the institutional arrangements that can be put in place.

\subsection{Seasonal variations and implications on availability of firewood}

As indicated in Table 2, firewood for domestic use was chosen by the majority as the main forest product. Table 5 shows that the majority of the respondents $(93.3 \%)$ agreed that there were seasonal variations in the collection of firewood.

Table 5. Seasonal variation in firewood availability

\begin{tabular}{lll}
\hline Aspect of variation in firewood collection & Frequency & Percentage \\
\hline $\begin{array}{l}\text { There is effect of seasonal variation on availability and } \\
\text { collection of firewood }\end{array}$ & \\
$\quad$ Yes & 279 & 93.3 \\
$\quad$ No & 20 & 6.7 \\
\hline $\begin{array}{l}\text { Firewood is collected more in the: } \\
\quad \quad \text { Dry season }\end{array}$ & 284 & 96.9 \\
- Wet season & 9 & 3.1 \\
\hline $\begin{array}{l}\text { Reasons for variations in the firewood collection in } \\
\text { different seasons: }\end{array}$ & \\
$\quad$ - The wood is fresh in wet season and cannot be used & 106 \\
$\quad$ as firewood & 79 & 35.3 \\
- There is more dry wood in dry season & 73 \\
- Access to the forest is difficult in wet season & 26.3 \\
- Do not collect firewood in wet season & 24.3 \\
- People engaged more in farming activities in wet & 12 & 7.7 \\
$\quad$ season & & 4.0 \\
\hline
\end{tabular}




\begin{tabular}{llll}
\hline- & $\begin{array}{l}\text { More in wet season because there is variability in } \\
\text { products }\end{array}$ & 7 & 2.3 \\
\hline
\end{tabular}

The main determining factors were availability of firewood and access to the forest area. About $96.9 \%$ of the people indicated that they collected more firewood in dry season than wet season. The reasons given were that wood was fresh in wet season; more dry wood was available in the dry season; and that access to the forest was more difficult in the wet season (dense and slippery). In addition, people were involved more in agricultural activities during the wet season and therefore had less time and labour for firewood collection. Similar findings were reported by Fisher $(2002,2005)$ in a study conducted in Mulanje district, Malawi. However, other products such as thatch grass and bamboos were collected depending on demand. This is consistent with what Awasthi et al. (2003) reported on seasonal variation in resource extraction in India which varied depending on the uses of the different products.

\subsection{Effects of the IFMSL program on forest access and livelihoods}

\subsubsection{Community organisation and participation}

In promoting community organisation and participation, the program was trying to build the social and human capitals of the community. Social capital allows for the increase in trust, cooperativeness, assertiveness, collective action and general capabilities of natural resource governance (Pretty 2003; Murali 2006; Sangita, 2008). However, household interviews and group discussion revealed that despite the participatory approach taken by the program, the community is not fully mobilised. Only $28 \%$ of the households interviewed belonged to a local forest organisation (LFO) and fewer participated in program activities (Table 1). As such only those that were committee members and those who participated in program activities, received training and other capacity building activities to improve their knowledge and skills (human capital) in forest management. These LFOs included block management committee, village natural resources committee and forest user groups. The forest user groups were expected to facilitate participation in management and utilisation of the forest resources by the forest users. . Belonging to a forest related group, under either co-management or joint forest management, provides users with rights to extract forest products and exclude those that do not hold the rights. However, the state retains ownership of the resources. This acts as a motivation to participate in collective forest activities (Maskey et al. 2006). However, this is not the case in the study area where only about $19 \%$ of the respondents participated in program activities.

\subsubsection{Access to forest products}

Access to forest products provides a physical capital that allows the community get resources for use in different livelihood strategies. The different aspects of forest access are summarized in Table 6 . The results revealed that $59 \%$ of the respondents indicated that they needed permission to enter the forest area, $33.6 \%$ did not while $7.5 \%$ did not enter the forest area. Similarly, on the need to get permission to harvest forest products, $65.4 \%$ indicated that they needed permission to harvest the forest products. Some respondents (58.4\%) went further to indicate that they paid for the permit to harvest forest products. The management plans specified both wood and non-wood products that users were allowed to harvest. These included timber, poles, curios, fuel wood, 
medicine, fruits, mushroom, wild relish and bush meat. In order to regulate extraction of forest products, the program facilitated the establishment of a local licensing system which was aimed at controlling access to forest products in the forest blocks.

Table 6. Aspects of forest access

\begin{tabular}{|c|c|c|}
\hline Aspect of forest access & Frequency & Percentage \\
\hline \multicolumn{3}{|l|}{ Permission to enter forest area } \\
\hline Required & 174 & 59.0 \\
\hline Not required & 99 & 33.6 \\
\hline Do not enter forest & 22 & 7.5 \\
\hline \multicolumn{3}{|l|}{ Permission to harvest forest products } \\
\hline Required & 193 & 65.4 \\
\hline Not required & 64 & 21.7 \\
\hline Do not harvest & 38 & 12.9 \\
\hline \multicolumn{3}{|l|}{ Permit granting authority } \\
\hline Department of forestry & 121 & 58.7 \\
\hline VNRMC & 47 & 22.8 \\
\hline Village Head & 24 & 11.7 \\
\hline Owner of forest & 8 & 3.9 \\
\hline FUG chairperson & 6 & 2.9 \\
\hline \multicolumn{3}{|l|}{ Permit fee } \\
\hline Yes & 169 & 58.4 \\
\hline No & 79 & 28.1 \\
\hline Do not harvest forest products & 38 & 13.5 \\
\hline \multicolumn{3}{|l|}{ Change in granting permission } \\
\hline \multicolumn{3}{|l|}{ Over last five years } \\
\hline No & 114 & 42.1 \\
\hline Do not know & 86 & 31.7 \\
\hline Yes & 71 & 26.2 \\
\hline \multicolumn{3}{|l|}{ In future } \\
\hline Do not know & 109 & 41.3 \\
\hline Yes & 80 & 30.3 \\
\hline No & 75 & 28.4 \\
\hline \multicolumn{3}{|l|}{ Reasons for response } \\
\hline - Unaware of the process and past trends & 65 & 29.5 \\
\hline - To protect and sustain forest resources & 60 & 27.3 \\
\hline - Have not changed for a long time & 26 & 11.8 \\
\hline - Change in operating environment & 24 & 10.9 \\
\hline - Change in governance of forest resources & 23 & 10.5 \\
\hline
\end{tabular}

The Block Management Committee (BMC), a local forestry organisation mandated with managing the co-management area, was given authority to issue permits for forest products for subsistence use and licences (at a fee) for commercial purposes. The BMC was provided with 
documentation to facilitate implementation of the system. However, household interviews revealed that $40.3 \%$ of respondents indicated that DoF was responsible for granting permission to harvest products, while $28.4 \%$ indicated a community based authority. This result meant that, despite the co-management agreement, authority to license forest use had not been completely handed over to the community organizations. It further implied that the program did not result in transfer of authority to grant access to forest products as expected. This is supported by $42.1 \%$ of the respondents who indicated that the process of issuing permits for forest use had not changed over the last five years. Only about a quarter of the respondents $(26.2 \%)$ indicated that the process changed, while $31.7 \%$ indicated that they did not know whether the process changed. Furthermore, some of the households interviewed indicated that the regulated access to products and services which was introduced by the program, had negative changes in their livelihoods. These included walking long distances to get forest products; reducing reliance on forest products; and turning to alternatives to forest products. And yet for others, the opposite were true. Similar outcomes were reported by Kajembe and Kessy (2000) in Tanzania where users travelled longer distance to get to alternative sources of forest products outside joint forest management sites, when PFM was adopted for management of Urumwa forest reserve. Introduction of co-management also brought the requirement for users to pay fees prior to harvesting forest products for sale. This institutional arrangement had increased income sources for the community. However, as Vyamana et al. (2009) pointed out, this arrangement can become a disadvantage to the very poor and poor households who are unable to pay the user fees and therefore unable to exercise their right to harvest forest products for sale. .

\subsubsection{Changes in forest product availability}

One of the major factors that are critical in defining availability of the desired forest products collected by the people is time taken to collect the product. A majority of the people $(72.9 \%)$ indicated that they were taking more time to collect their desired products than the previous five years. In addition, $88 \%$ of respondents also indicated that the availability of forest products had declined. This period coincided with the introduction of the co-management program under IFMSLP. This was attributed to increased use of the forest resources by people from within $(53.3 \%)$ and other villages (11.1\%), and clearing of forest for agriculture (19.3\%).

Table 7. Status and factors affecting forest products availability

\begin{tabular}{|c|c|c|}
\hline Aspect of product availability & Frequency & Percentage \\
\hline \multicolumn{3}{|c|}{$\begin{array}{l}\text { Time taken to collect forest product as compared five years } \\
\text { ago }\end{array}$} \\
\hline - More time & 218 & 72.9 \\
\hline - $\quad$ Less time & 36 & 12.0 \\
\hline - Same amount of time & 27 & 9.0 \\
\hline - Did not collect five years ago & 18 & 6 \\
\hline
\end{tabular}




\begin{tabular}{|c|c|c|}
\hline \multicolumn{3}{|l|}{ Change in product availability over past five years } \\
\hline - It has declined & 254 & 85.5 \\
\hline - $\quad$ Did not collect five years ago & 18 & 6.0 \\
\hline - I has remained the same & 10 & 3.4 \\
\hline - It has improved & 9 & 3.0 \\
\hline - Not sure & 6 & 2.0 \\
\hline \multicolumn{3}{|l|}{ Reasons for decline } \\
\hline $\begin{array}{l}\text { - More people within the village collecting more } \\
\text { firewood for subsistence and sale }\end{array}$ & 144 & 53.3 \\
\hline - $\quad$ Reduced forest area due to subsistence agriculture & 53 & 19.6 \\
\hline $\begin{array}{l}\text { - More people from outside the village collecting more } \\
\text { firewood }\end{array}$ & 30 & 11.1 \\
\hline $\begin{array}{l}\text { - Reduced forest area due to people from outside buying } \\
\text { land and restricting access }\end{array}$ & 17 & 6.3 \\
\hline $\begin{array}{l}\text { - Reduced forest area due to large-scale projects } \\
\text { (plantations, new settlements, etc.)" }\end{array}$ & 9 & 3.3 \\
\hline - Climatic changes, e.g., drought and less rainfall & 8 & 3.0 \\
\hline - Charcoal making & 3 & 1.1 \\
\hline - Restrictions on use by central or state government & 2 & 0.7 \\
\hline - Local restrictions on forest use & 2 & 0.7 \\
\hline - $\quad$ Increased illegal harvesting & 0 & 0 \\
\hline
\end{tabular}

Interestingly, none of the respondents indicated increased illegal harvesting as one of the major factor that lead to decrease in the forest products and yet the transect walk revealed evidence of illegal activities and general degradation in form of cutting of live trees, debarking and new agricultural fields. A plausible explanation could be fear of being apprehended (if involved) or fear of retaliation from fellow villagers if the respondent showed knowledge of illegal activities by others. Household interviews revealed that despite the participatory approach taken by the program, majority of the people $(72 \%)$ did not belong to any forest related group, while the group discussion revealed that majority of those in attendance did not participate in the implementation of planned forest activities. This result points to inadequate organisation for collective action which would have facilitated local enforcement to reduce illegal harvesting of forest products. Illegal extraction of forest products contributes to forest degradation which threatens the very resource that livelihoods are dependent on (Kaimowitz 2003; Chhatre and Agrawal 2008). However, local enforcement and local collective action can mitigate negative outcomes resulting from resource use even in areas that people are heavily dependent on the resource for their livelihood (Chhatre and Agrawal, 2008)

\subsubsection{Commercialization of forest products}

Commercialisation of forest products represents financial capital and can contribute significantly to rural household income as well as poverty reduction (Shackleton et al. 2008; Bwalya 2011). The IFMSL program facilitated a process of setting up forest based enterprises (FBEs) as a way 
of making better use of forest products. Therefore, the program facilitated the development of Enterprise Development Plans (EDPs). The choice on the type of FBE to develop was based on results of a participatory resource assessment which resulted in demarcation of the block into forest management units according to the key product in that particular area and determination of the annual allowable cut. The EDPs were developed for firewood, curio making (wood carving) and bee keeping. These FBEs were at different levels of development: both the bee keeping group and the curio group had been in existence even before the program but the program provided support to them strengthen further. The program provided material support to the bee keeping group in form of bee hives, bee suits, smokers and packaging materials. However, this support was not adequate to support additional bee keeping groups, which would have otherwise provided a better alternative to wood based FBEs. The curio group was supported by constructing a market centre (single building) along a road leading to tourist attraction centres in the Lake Malawi shore area of Mangochi. However, relocation of the road has led to the abandonment of the market centre, with curio makers opting to build make shift shelters along the new road. For bee keeping, the group indicated that they had limited capacity to manage their FBE as only one individual was trained, in addition to lacking processing and storage facilities. Firewood as an FBE was abandoned due to high transportation costs to access more viable and profitable markets. These constraints discouraged the group as such the FBE was abandoned. The constraints being faced by the FBEs are consistent with constraints reported by Kambewa and Utila (2008) in a study of small and medium forest enterprises in Malawi. They recommended security of access to forest resources, formation and strengthening of producer associations, access to credit and linkage to institutions with substantial experience in development of FBEs to ensure FBEs contribute to the local economy and poverty reduction.

\subsection{Community perception of the Improved Forest Management for Sustainable Livelihoods program (IFMSLP)}

Table 8 provides results on the perception of the households on the different aspects of the IFMSL program. Despite the participatory approach that was used to introduce the PFM program (IFMSLP); the study revealed that the majority of the respondents $(51.7 \%)$ were not knowledgeable about the objectives of the program. This is also reflected in the inability of the majority (58\%) to express whether the program was meeting the community's needs and interests. This might be attributed to the low contact that the people had with the program.

Table 8. Community awareness of the IFMSL program

\begin{tabular}{lll}
\hline Aspect & Frequency & Percentage \\
\hline Knowledge of the program's objectives* & & \\
- No knowledge & 155 & 51.7 \\
- Protection of forest resources & 98 & 32.7 \\
- Promoting sustainable use of forests & 93 & 31.0 \\
- Empowerment of community members & 59 & 19.7 \\
- Creating sense of ownership over services & 46 & 15.3 \\
- Improving people's livelihoods & 67 & 22.3 \\
\hline Meeting community needs and interest & & \\
- Yes & 126 & 42.0 \\
- No idea & 174 & 58.0 \\
\hline
\end{tabular}




\begin{tabular}{lll}
\hline Reason program met community needs and interests & \\
- Sustainability of forests & & \\
- Sustain benefits provided by forest & & \\
- Community empowerment & & \\
- Improvement in forest condition & & \\
- Effective management of the resources & & \\
- Livelihood improvement & 211 & 70.6 \\
Contact with program & 32 & 10.7 \\
- None & 56 & 18.7 \\
- Through LFO membership & \\
- Participation in program activities & 163 & 54.7 \\
\hline Knowledgeable about program & 72 & 24.2 \\
- Low (1-3) & 63 & 21.1 \\
- Medium (4-7) &
\end{tabular}

\footnotetext{
*multiple responses; the percentages do not add to 100 as they reflect proportion of respondents for each objective to the total
}

The low contact might have created a gap in knowledge to enable people understand what the objectives of the program were, and how they fit with their own individual and collective forest management objectives. Although the respondents indicated lack of knowledge in objectives of the program, their attitudes towards the program were surprisingly positive because of the impact they had seen. They indicated that they have seen a reduction in illegal activities and attributed it to the existence of the program. Barr (2004) reported that people with more positive orientations towards forestry programs in general are more likely to act in more appropriate ways. It is therefore assumed that people would be more willing to take action to improve the status and condition of their forests.

\subsection{Actions to increase benefits from forest products}

Sustainable forest management holds the key to maintaining the benefits that forests provide (FAO, 2014). In order to increase benefits from products they get from the forest, the household interviewed proposed actions to be implemented to achieve this (Table 9).

Table 9. Actions to increase benefits from forest products

\begin{tabular}{|c|c|c|}
\hline Action & Frequency & Percentage \\
\hline - Better protection of forest to avoid over use & 144 & 50.9 \\
\hline $\begin{array}{l}\text { Better skills and knowledge on how to } \\
\text { collect and use the products }\end{array}$ & 53 & 18.7 \\
\hline $\begin{array}{l}\text { - Better access to the forest, i.e. more use and } \\
\text { control rights to village }\end{array}$ & 52 & 18.4 \\
\hline $\begin{array}{l}\text { Better access to capital and equipment for } \\
\text { value addition }\end{array}$ & 16 & 5.7 \\
\hline - Reforestation & 11 & 3.9 \\
\hline
\end{tabular}


- Better access to market

- Establishing forests closer to home

- Livelihood diversification to reduce dependency on the forest

- Combat charcoal production
$5 \quad 1.8$

10.3

$1 \quad 0.3$

$0 \quad 0$

The three main actions they perceived could increase benefits from forest products included: firstly, better protection of the forest from overuse (50.9\%). Improvements in management of the forest area can reduce incidences of illegal cutting and logging, resulting in visible improvement in the condition of the forests (Ali et al. 2007, Mauambeta and Kafakoma 2010). This therefore, would present the possibility of sustaining benefit flows through regulated use Secondly, the respondents felt better skills and/or knowledge on how to collect and use the products (18.7\%), would increase benefits from forest products. Managing forest resources is challenging and therefore requires skills and knowledge to strengthen implementation capacities (FAO 2014). The knowledge enables the rural communities to potentially achieve sustainable yields from their forest resources (CELT 2013 unpubl.). Thirdly, respondents opted for better access to capital and equipment for value addition (18.4\%). The provision of microfinance services is necessary for building financial and business management capacity of rural communities (FAO, 2005; Demont 2013). Access to credit enables the rural communities to acquire the necessary capital and equipment to start up and/ or expand their enterprises (Tomaselli et al. 2013). This allows them to convert the raw forest products into products that satisfy the value sought by the market. Increasing resource value has been touted as an incentive to manage forest resources more sustainably (Dawson et al. 2014; FAO 2010, 2014; Tomaselli et al. 2013).

\section{CONCLUSION}

The study evaluated how outsider facilitated PFM resulted in regulated forest use and improved livelihoods of ruralcommunities living adjacent to Mua -Livulezi Forest Reserve in Dedza district, Malawi. Specifically, it examined household forest use and the factors that influence the use, as well as perception on availability of forest products. The results have shown that PFM has not resulted in the expected outcomes in utilisation of forest products and livelihoods. While other research results have shown substantial contribution of forests to household income in Malawi (see Fisher 2002; Jumbe and Angelsen 2006; Kamanga et al. 2009), this study revealed that households adjacent to Mua-Livulezi Forest Reserve depend on the forest mainly for subsistence use with minimal use as a source of income. The results indicated that forest use was positively influenced by such household socio-economic characteristics as location of household, age, gender, education, household size, land size and proximity to forest area. Understanding these factors is essential when developing strategies that integrate interests of various community groups, to achieve improved access to and participation in management of forest resources. The inadequate development of markets resulted in downplaying the importance of other forest resources which could contribute more to livelihoods. It is recommended that current forest based enterprises should be revamped by carrying out a thorough market analysis and an assessment of opportunities for new products development. Reliance on the forest reserve as a source of firewood by majority of the households has exerted pressure on the resource. There is, therefore, need for proper regulation of firewood collection in order to ensure that extraction 
matches the capacity of the resource. This should be done in cognizance of the fact that accessible and affordable alternative sources of energy are limited and thereby ensuring the sustainability of the resource base.

Inadequate control of access to and use of forest products has led to opportunistic behaviour from members of the community that are able to have unauthorised access resulting in decline of forest resources. The establishment of co-management by the IFMSLP was expected to strengthen community-based institutions for managing forests (both communal and forest reserves) and encouraging individuals, households and communities to participate in forest management activities. Despite the technical assistance provided by the program, this has been ineffective with respect to community organisation, access to forest products, resource availability and commercialisation of the products. This resulted in low participation of the people in the co-management activities. It is therefore, recommended that the process of community mobilisation should be revisited to secure willingness and commitment of community members to participate in forest management activities. It is hoped that this would enable users to gain access to and some control over forest resources necessary for improved livelihoods. Furthermore, a multi-institutional approach should be adopted to draw upon diverse talents and experiences from individual institutions such as government departments, nongovernmental organisations and research/training institutions, in order to achieve meaningful social change. Further data collection on forest use at household level over long period of time is recommended to better explain local heterogeneity and social differentiation as it relates to forest use and management. It is hoped this will in turn address challenges faced, including institutional arrangements and management of the resource to improve livelihoods of communities.

\section{ACKNOWLEDGEMENTS}

Acknowledgment to the University of Pretoria for provision of the Postgraduate bursary to the first author which enabled her to undertake this study. Field work for this research was supported by World Wide Fund for Nature through the Russell E. Train Education for Nature (EFN) Program (Grant no. RF19). Thanks to the community members sampled in Mua and Mtakataka for their contribution in this study. Appreciation also goes to the Diploma in Forestry class at Malawi College of Forestry and Wildlife (DCT23) and to the District Forestry staff at Dedza boma and Mtakataka EPA for all the support in the data collection.

\section{REFERENCES:}

Adedayo AG, Oyun MB, Kadeba $\mathrm{O}(2010)$ Access of rural women to forest resources and its impact on rural household welfare in North Central Nigeria. For Policy Econ 12(6):439-450. Available at: http://dx.doi.org/10.1016/j.forpol.2010.04.001.

Adhikari B, Di Falco S, Lovett JC (2004) Household characteristics and forest dependency: evidence from common property forest management in Nepal. Ecol Econ 48 (2004) 245257. 
Ali T, Ahmad M, Shahbaz B, Suleri A (2007) Impact of participatory forest management on vulnerability and livelihood assets of forest-dependent communities in northern Pakistan. Int.J Sust Dev World 14 (2): $211-223$

Angelsen A, Kaimowitz D (1999) Rethinking causes of deforestation: Lessons from Economic models. The World Bank Research Observer 14 (1): 73-98

Angelsen A,Wunder S (2003) Exploring the poverty-forest link: key concepts, issues and research implications. CIFOR Occasional Paper No. 40

Angelsen A, Larsen HO, Lund JF, Smith-Hall C, Wunder S (ed)(2011) Measuring Livelihoods and Environmental Dependence. Methods for Research and Fieldwork. Earthscan. London; Washington, DC.

Awasthi A, Uniyal SK, Rawat GS, Rajvanshi A (2003) Forest Resource availability and its use by the migratory villages of Uttarkashi, Garhwal Himalaya (India). Forest Ecol Manag 174:13-24.

Babulo B,Muys B, Nega F, Tollens E, Nyssen J, Deckers J, Mathijs E (2008) Household livelihood strategies and forest dependence in the highlands of Tigray, Northern Ethiopia. Agr Syst 98:147-155.

Barr S (2004) Are we all environmentalists now? Rhetoric and reality in environmental action. Geoforum 35: 231-249

Barret CB, Bezuneh M, Aboud A (2001) Income diversification, poverty traps and policy shocks in Cotê d'Ivoire and Kenya. Food Policy 26:367-384

Barrow E, Fisher RJ, Emerton L, Ingles A (2007) Forests, livelihoods and the millennium development goals in Tanzania and LAO PDR. In: Willemine B, Erika vanD, Nicole A (eds) European Tropical Forest Research Network News (ETFRN): Forests and the Millennium Development Goals. No. 47-48, pp. 17-20.

Biran A, Abbot J, Mace R (2004) Families and firewood: A comparative analysis of the costs and benefits of children in firewood collection and use in two rural communities in SubSaharan Africa. Human Ecol 32(1).

Blaikie P (2006). Is small beautiful? Community-based natural resources management in Malawi and Botswana. World Dev 34 (11): 1947-1957

Blomley T, Ramadhani H (2006) Going to scale with participatory forest management: early lessons from Tanzania. Int For Rev8(1):93-100. Available at: http://www.atyponlink.com/CFA/doi/abs/10.1505/ifor.8.1.93.

Bwalya SM (2011) Household Dependence on Forest Income in Selected Rural communities in Zambia. Zambia Soc Sci J 2(1): 66-86.

Carney D (2002) Sustainable livelihood approaches: progress and Possibilities for change. DFID, London.

Cavendish W (2000) Empirical irregularities in poverty-environment relationship of rural households: Evidence from Zimbabwe. World Dev 28 (11): 1997-2003.

Cavendish W (2003). How do forests Support, insure and improve livelihoods of the rural poor? A Research note. CIFOR

Chao S (2012) Forest people's: numbers across the world. Forests People Program.

Chhatre A, Agrawal A (2008) Forest commons and local enforcement. P Natl Acad Sci USA105 (36): 13286-13291

Chidumayo EN, Marunda C (2010) Dry Forests and Woodlands in Sub-Saharan Africa: Context and Challenges. In Emmanuel N. Chidumayo, Davison J. Gumbo (Eds). The Dry Forests 
and Woodlands of Africa Managing for Products and Services. Earthscan. London.

Washington, DC.

CIFOR (2008) PEN prototype questionnaire. Version 4.4. Poverty Environment Network. CIFOR

Cooke P, Köhlin G, Hyde WF (2008) Firewood, forests and community management - evidence from household studies. Environ Dev Econ 13: 103 -135.

Coulibaly-Lingani P, Tigabu M, Savadogo P, Oden P, Ouadba J (2009) Determinants of access to forest products in southern Burkina Faso. For Policy Econ 11(7):516-524.

Dawson IK, Leakey R, Clement CR, Weber JC, Cornelius JP, Roshetko JM, Vinceti B, Kalinganire A, Tchoundjeu Z, Masters E, Jamnadass R (2014) The management of tree genetic resources and the livelihoods of rural communities in the tropics: Non-timber forest products, smallholder agroforestry practices and tree commodity crops. Forest Ecol Manag 333: 9-21.

Department of Forestry (2007) Mua-Livulezi Strategic Forest Area Plan. Dedza.

Demont T (2013) Poverty, access to credit and absorption of weather. Available on www.ecineq.org/ecineq_bari13/FILESxBari13/CR2/p198.pdf. Accessed 15/03/2015

Dewees PA, Campbell BM, Katerere Y, Sitoe A, Cunningham AB, Angelsen A, Wunder S (2010) Managing the miombo woodlands of Southern Africa: Policies, incentives and options for the rural poor. J Nat Resour Policy Res 2 (1): 57-73

DFID (1999) Sustainable Livelihoods Guidance Sheets. London: UK Department for International Development.

FAO (2005) Microfinance and forest-based small-scale enterprises. FAO Forestry paper 146. Food and Agriculture Organization of the United Nations, Rome, Italy.

FAO (2010) Global forest resources assessment 2010. FAO Forestry Paper No. 163. Food and Agriculture Organization of the United Nations, Rome, Italy.

FAO (2014) State of the world's forests: enhancing the socioeconomic benefits from forests. Food and Agriculture Organization of the United Nations.

Fisher MG (2002) Explaining forest degradation in Malawi: asset poverty, incomeShocks and activity Choice. PhD Thesis. Purdue University.

Fisher MG (2004) Household welfare and forest dependence in southern Malawi. Environ Dev. Econ 9(2):135-154.

Fisher M, Shively G (2005) Can income programs reduce tropical forest pressure? Income shocks and forest use in Malawi. World Dev 33 (7): 1115-1128

GoM (2005) Standards and guidelines for participatory forestry in Malawi: Improving forest governance, improving livelihoods. Department of Forestry. USAID/European Union.

GoM (2008). Population and housing census. National Statistical Office (NSO). Zomba, Malawi

GoM (2013) Dedza District Socio-Economic Profile: 2013 -2018

Godoy R, O'Neill K, Groff S, Kostishack P, Cubas A, Demmer J, McSweeney K, Overman J, Wilkie D, Brokaw N, Martinez M(1997) Household determinants of deforestation by Amerindians in Honduras. World Dev 25: 977-987.

Gutierrez Rodriguez L, Ruíz-Pérez M, Yang X, Fu M, Geriletu G, Wu D(2009) Changing contribution of forests to livelihoods: evidence from Daxi Village, Zhejiang Province, China. Int For Rev 11(3): 319-330.

Hegde R (2010) Payments for ecosystems services and farm household behavior: the case of carbon in Mozambique's agro-forests. PhD Dissertation. Faculty of Graduate Studies in Forestry at the University of British Columbia, Vancouver, Canada. 
Hogarth NJ, Belcher B (2013)The contribution of bamboo to household income and rural livelihoods in a poor and mountainous county in Guangxi, China. Int For Rev 15(1), pp11

IFMSLP (2007) Baseline report: Improved Forest Management for Sustainable Livelihoods program (IFMSLP). Final version. A report compiled as part of the program's monitoring and evaluation system.

Jagger P (2012) Environmental income, rural livelihoods, and income inequality in western Uganda, Forests, Trees and Livelihoods, 21:2, 70-84, DOI: 10.1080/14728028.2012.698846

Jha S (2008) Household-specific variables and forest dependency in an Indian hotspot of biodiversity: challenges for sustainable livelihoods. Environment, Development and Sustainability 11(6):1215-1223. Available at: http://www.springerlink.com/index/10.1007/s10668-008-9175-y [Accessed June 30, 2011].

Jumbe CBL, Angelsen A (2006) Household's choice of firewood source in Malawi:A multinomial probit analysis. Contributed paper prepared for presentation at the International Association of Agricultural Economists Conference, Gold Coast, Australia August 12-18, 2006.

Kabubo-Mariara J(2008) Forest dependence and household welfare: empirical evidencefrom Kenya. CEEPA Discussion Paper No 41, Centre for Environmental Economics and Policy in Africa, University of Pretoria.

Kaimowitz D (2003) "Not by Bread Alone. Forests and Rural Livelihoods in Sub-Saharan Africa".In: Oksanen T, Pajari B, Tuomasjukka T (eds.). Forests in Poverty Reduction Strategies: Capturing the Potential. EFI Proceedings No. 47: 45-64. European Forest Institute, Finland.

Kajembe GC, Kessy JF (2000) Joint forest management in Urumwa Forest Reserve, Tabora, Tanzania: A process in the making.In:VirtanenP, NummelinM (eds)Forests, chiefs and peasants in Africa: Local management of natural resources in Tanzania, Zimbabwe and Mozambique. University of Joensuu, Finland. Silva Carelica, 34:141-58.

Kamanga P, Vedeld P, Sjaastad E (2009) Forest incomes and rural livelihoodsinChiradzulu District, Malawi. Ecol Econ 68:613-624.

Kambani C (2005) Forest Resource Utilization, Local Participation and Management: A Study of Namizimu Forest Reserve in Lungwena, Southern Malawi. MSc thesis, Department of International Environment and Development Studies, Norwegian University of Life Sciences.

Kambewa P, Utila H (2008) Malawi's green gold: challenges and opportunities for small and medium forest enterprises in reducing poverty. IIED Small and Medium Enterprises Series No. 24. Chancellor College, Forest Research Institute of Malawi and the International Institute for Environment and Development, London, UK.

Kayambazinthu D (2000) Empowering communities to manage natural resources: where does the power lie? - The case of Malawi. In: Shackleton S, Campbell B (eds.), Empowering communities to manage natural resources: case studies from southern Africa. CIFRO, USAID, IUCN, WWF, Africa Resources Trust, CSIR, and IES.

Mamo G, Sjaastad E, Vedeld P (2007) Economic dependence on forest resources: A case from Dendi district, Ethiopia. For Policy Econ 9: 916-927

MaskeyV, Gebremedhin TG, Dalton TJ (2006) Social and cultural determinants of collective management of community forest in Nepal. J Forest Econ 11: 261-274 
Matose, F. (2008) Towards Community-Based Forest Management in Southern Africa: Do Reforms Lead to Improved Livelihoods for the Poor? A paper presented at a Workshop on Forest Governance and Decentralization in Africa. 8-11 April 2008. Durban, South Africa.

Mauambeta DDC, Kafakoma RPG (2010) Study report on CBNRM stocktaking in Malawi. Malawi CBNRM Forum/Development Alternatives Inc.

Menzies NK(2002) "Global Gleanings". Lessons from six studies of community based forest management around the world. A report prepared for the Ford Foundation's Environment and Development Affinity Group (EDAG).

Murali KS (2006) Microfinance, social capital and natural resource management systems: conceptual issues and empirical evidences. Int. J. Agr Res GovernEcol 5 (4): 327-337

Njana MA, Kajembe GC, Malimbwi RE (2013) Are miombo woodlands vital to livelihoods of rural households? Evidence from Urumwa and surrounding communities, Tabora, Tanzania, Forests, Trees and Livelihoods, 22 (2):124-140. DOI: 10.1080/14728028.2013.803774

Ngulube MR (2000) The utilization of non-timber forest products from the miombo woodlands of Malawi: a case study. In: Mzoma R. Ngulube, Lusayo Mwabumba, Paxie Chirwa (Eds). Community based management of Miombo Woodlands in Malawi, Forestry Research Institute of Malawi, Zomba, Malawi. $251 \mathrm{pp}$.

Palinkas LA, Horwitz SM, Green CA, Wisdom JP, Duan N, Hoagwood K (2013) Purposeful Sampling for Qualitative Data Collection and Analysis in Mixed Method Implementation Research. Administration and Policy in Mental Health. DOI 10.1007/s10488-013-0528-y Palys F (2008) Purposive sampling. In: Given LM (ed.) The Sage Encyclopedia of Qualitative Research Methods. Sage: Thousand Oaks, CA, Vol.2, pp.697-698.

Paumgarten F (2005) The role of non-timber forest products as safety-nets: A review of evidence with a focus on South Africa. GeoJournal 64: 189-197.

Peng CJ, Lee KL, Ingersoll GM (2002) An Introduction to Logistic Regression Analysis and Reporting. J Educ Res 96 (1):3 -14.

Pouliot M, Treue T (2012) Rural people's reliance on forests and the non-forest environment in West Africa: Evidence from Ghana and Burkina Faso, World Dev (2012). http://dx.doi.org/10.1016/j.worlddev.2012.09.010

Pretty J (2003) Social capital and the collective management of resources. Science 302 (5652):1912-1914.

Ra K, Pichdara L, Dararath Y, Jiao X, Smith-Hall C (2011) Towards understanding household level forest reliance in Cambodia - study sites, methods, and preliminary findings. Forest and Landscape Working Papers no. 60. Forest and Landscape, Denmark.

Salafsky N, Wollenberg E (2000) Linking livelihoods and conservation: A conceptual framework and scale for assessing the integration of human needs and biodiversity. World Dev 28 (8): 1421-1438.

Sangita SN (2008) Social capital in forest governance regimes. Institute for Social and Economic Change (ISEC) Working Paper 190.

Saptoka IP, Odén PC (2008) Household characteristics and dependency on communityforests in Terai of Nepal. Int J Soc For 1(2):123-144.

Schreckenberg K, Luttrell C, Moss C (2006).Participatory forest management: an overview.Forest Policy and Environment Programme: Grey Literature. World Dev.

Scoones I (1998) Sustainable rural livelihoods: a framework for analysis. IDS Working Paper 72. Shackleton S, Gumbo D (2010) Contribution of Non-wood Forest Products to Livelihoods and Poverty Alleviation. In Emmanuel N. Chidumayo, Davison J. Gumbo (Eds). The Dry Forests 
and Woodlands of Africa Managing for Products and Services. Earthscan, London.

Washington, DC.

Shackleton CM, Shackleton SE (2006) Household wealth status and natural resource use in Kat River valley. South Africa. Ecol Econ 57: 306 -317

Shackleton C, Shackleton S (2004) The importance of non-timber forest products in rural livelihood security and as safety nets: a review of evidence from South Africa. SA J Sci 100: $658-664$.

Shackleton S, Paumgarten F, Kassa H, Husselman M, Zida M (2011) Opportunities for enhancing poor women's socioeconomic empowerment in the value chains of three African non-timber forest products (NTFPs). Int For Rev13 (2): 136- 151

Shackleton S, Campbell B, Lotz-Sisitka H, Shackleton C (2008) Links between the local trade in natural products, livelihoods and poverty alleviation in a semi-arid region of South Africa. World Dev 36(3): 505-526.

ShackletonCM, ShackletonSE, Buiten E, Bird N (2007) The importance of dry woodlands and forests in rural livelihoods and poverty alleviation in South Africa. For Policy Econ 9: 558577

Scheaffer RL, Mendenhall III W, Ott RL, Gerow K (2012) Elementary Survey Sampling. Seventh Edition. Brooks/Cloe, Cengage Learning. Canada

Sunderland T, Achdiawan R, Angelsen A, Babigumira R, Ickowitz A, Paumgarten,F, ReyesGarciá V, Shively G(in press). Challenging Perceptions about Men, Women, and Forest Product Use: A GlobalComparative Study, World Dev (2014), http://dx.doi.org/10.1016/j.worlddev.2014.03.003

Sunderlin WD, Angelsen A, Wunder S (2003) Forests and poverty alleviation. In: State of the world's forests. FAO, Rome. Pp. 61-73

Sunderlin WD, Angelsen A, Belcher B, Burgers P, Nasi R, Santoso L, Wunder S (2005) Livelihoods, forests and conservation in developing countries: a review. World Dev 33:13831402.

Suri H (2011) 'Purposeful Sampling in Qualitative Research Synthesis'.Qual Res J 11 (2): 63-75. DOI 10.3316/QRJ1102063.

Syampungani S, Chirwa PW, Akinnifesi FK, Chileshi G, Ajayi OC (2009) The Miombo Woodlands at the cross roads: Potential threats, sustainable livelihoods, policy gaps and challenges. Nat Resour Forum 33: 150-159.

Thin N, van Gardingen P (2004) Participatory Forestry: sharable lessons for better management of commons. Forests, Trees and Livelihoods 14:229-242.

Tomaselli MF, Timko J, Kozak R (2013) Assessing small and medium forest enterprises' access to microfinance: Case studies from The Gambia. J Dev Stud49(3): 334-347.

Tongco MA DC (2007) Purposive sampling as a tool for informant selection. Ethnobotany Research and Applications 5: 147-158

Tumusiime DM, Vedeld P, Gombya-Ssembajjwe W (2011) Breaking the law? Illegal livelihoods from a Protected Area in Uganda. For Policy Econ 13(4):273-283. Available at: http://linkinghub.elsevier.com/retrieve/pii/S1389934111000049 [Accessed June 30, 2011].

Vedeld P, Sjaastad E (2013) Forest environmental income and the rural poor. Retrieved from http://www.eoearth.org/view/article/152817. Accessed 8 June 2014.

Vedeld P, Angelsen A, Bojö J, Sjaastad E, Berg GK (2007) Forest environmental incomes and the rural poor. For Policy Econ 9: 869-879 
Vedeld A, Angelsen A, Sjaastad E, Berg GK (2004) Counting on the Environment: Forest Incomes and the Rural Poor. The World Bank Environment Department, Environmental Economics Series, Paper No. 98. Washington D.C.

Vyamana VG, Chonya AB, Sasu FV, Rilagonya F, Gwassa FN, Kivamba S, Mpessa I, Ndowo EA (2009) Participatory forest management in the Eastern Arc Mountain area of Tanzania : Who is benefiting? Int For Rev 11(2):239-253.

WFP (2010) WFP and Safe Access to Firewood Protecting and Empowering Communities. World Food Program

Warner K (2000) Forestry and sustainable livelihoods: What part can forests and forestry play in reducing poverty? Unasylva, 202, Vol. 51:3-12.

World Bank (2004) Sustaining Forests: a development strategy. World Bank, Washington D.C.

Yaron G, Mgoola W, John M et al. (2011) Economic Analysis of Sustainable Natural Resource Use in Malawi. Economic Study. Government of Malawi, UNEP and UNDP, Lilongwe, Malawi.

Yemiru T, Roos A, Campbell BM, Bohlin F (2010) Forest incomes andpoverty alleviation under participatory forest management in the Bale Highlands, Southern Ethiopia. Int For Rev12 (1):66-77.

Zulu LC (2010) The forbidden fuel: Charcoal, urban woodfuel demand and supply dynamics, community forest management and woodfuel policy in Malawi. Energy Policy 38: 37173730

Zulu L (2013) Bringing People Back into Protected Forests in Developing Countries: Insights from Co-Management in Malawi. Sustainability5: 1917-1943. 